\title{
UPAYA PERLINDUNGAN HUKUM TERHADAP PELANGGARAN MEREK TERKENAL YANG TIDAK TERDAFTAR DI INDONESIA BERDASARKAN UNDANG-UNDANG NOMOR 20 TAHUN 2016 TENTANG MEREK DAN INDIKASI GEOGRAFIS
}

\author{
${ }^{1}$ Muthia Septarina; ${ }^{2}$ Salamiah \\ Fakultas Hukum Universitas Islam Kalimantan Muhammad Arsyad Al-Banjari \\ Jl. Adhyaksa No. 2 Kayutangi Banjarmasin \\ E-mail: muthia.septarina@gmail.com \\ E-mail: salamiah_hamberi72@yahoo.com
}

\begin{abstract}
For the purpose of holding this research is to find out how legal protection are in violation of unregistered famous brands in Law No.20 of 2016 on Marks and Geographical Indications and to find out how famous brand registration process in the provisions in Law No 20 of 2016 On Marks and Geographical Indications. This research use normative juridical research method that is research that examines the legislation with problem investigated. To get transnational protection, Article 52 of Law No 20 of 2016 on Trademarks and Geographical Indications adds the provisions regarding "applications for registering international marks", namely those requests originating from Indonesia addressed to the international bureau and applications addressed to Indonesia as one of the destination countries of the International Bureau.
\end{abstract}

Key words: legal protection, violation, famous brands

\begin{abstract}
Abstrak
Adapun tujuan diadakannya penelitian ini adalah untuk mengetahui bagaimana upaya perlindungan hukum dalam pelanggaran merek terkenal yang tidak terdaftar dalam UU Nomor 20 Tahun 2016 tentang Merek dan Indikasi Geografis dan untuk mengetahui bagaimana proses pendaftaran merek terkenal menurut ketentuan dalam UU Nomor 20 Tahun 2016 Tentang Merek dan indikasi Geografis. Penelitian ini menggunakan metode penelitin yuridis normative yaitu penelitian yang mengkaji suatu peraturan perundang-undangan dikaitkan dengan permasalahan yang diteliti. Untuk mendapatkan perlindungan dalam pasal 52 UU Nomor 20 tahun 2016 tentang Merek dan Indikasi Geografis menambah ketentuan mengenai "permohonan pendaftarn merek internasional" yaitu mengenai permohonan yang berasal dari Indonesia ditujukan ke Biro internasional dan permohonan yang ditujukan ke Indonesia sebagai salah satu negara tujuan dari Biro Internasional.
\end{abstract}

Kata kunci: perlindungan hukum, pelanggaran, merek terkenal. 


\section{PENDAHULUAN}

Di dalam era perdagangan global saat ini peranan Merek menjadi sangat penting terutama dalam menjaga persaingan usaha yang sehat, karena bagi dunia usaha khususnya di bidang perdagangan Merek mempunyai arti yang sangat penting dan sangat tak ternilai harganya. Karena sebuah Merek tidak hanya sekedar nama, tetapi mencerminkan harga diri perusahaan, pengalaman perusahaan, dan jaminan mutu atas produk barang dan/atau jasa yang dihasilkan oleh sebuah perusahaan. Selain itu Merek juga merupakan pencerminan terhadap tingkat kepercayaan konsumen terhadap suatu barang dan/atau jasa. Suatu merek terkenal lebih mudah dipasarkan sehingga lebih banyak mendatangkan keuntungan financial bagi perusahaan atau pelaku usaha dagang dan/atau jasa.

Pada masyarakat Indonesia ada kecendrungan lebih menyukai pemakaian produk-produk luar negeri (label minded) apalagi kalau itu adalah merek terkenal sebagai contoh misalnya brand-brand ternama di bidang fashion seperti Guci, Luis Vuiton, Hermes, Chanel dan lain sebagainya. Akan tetapi tingkat daya beli masyarakat Indonesia masih sangat rendah terhadap barang-barang terkenal tersebut karena mereka menawarkan barang-barang fashion mereka dengan harga yang sangat tinggi. Sehingga tidak semua kalangan bisa membelinya, hal ini sangat bertolak belakang dengan keinginan yang besar untuk memakai produk-produk dengan merek-merek terkenal tersebut. Salah satu cara mengatasi nya adalah kemdian masyarakat lebih memilih membeli barang dengan tampilan yang serupa bahkan sama persis namun dengan kualitas dan harga yang sangat jauh dengan Merek aslinya.

Keadaan seperti tersebut di atas pada akhirnya semakin membuka peluang terhadap para pengusaha yang tidak mempunyai itikad baik untuk menggunakan merek terkenal orang lain terutama merek terkenal asing dan berusaha mendaftarkannya. Hal ini tentu saja berdampak pada kerugian yang sangat besar yang dialami pemilik Merek terkenal karena hak-hak intelektualnya telah dilanggar dan secara tidak langsung jua mengalami kerugian materiil yang sangat besar karena banyak konsumen yang beralih keppada barang yang serupa tapi tak sama tersebut.

Indonesia merupakan salah satu negara yang menjadi anggota WTO (World Trade Organization) dan Indonesia telah ikut meratifikasi persetujuan mengenai TRIP'S (Trade Relation Aspects of Intellectual Property Right) yang secara khusus mengatur mengenai hal-hal yang berkaitan dengan HKI (Hak Kekayaan 
Intelektual). Oleh karena nya lah maka Indonesia sangat diharapkan oleh para pelaku usaha baik itu berskala nasional maupun berskala internasional untuk dapat memegang teguh prinsip-prinsip yang telah dicantumkan dalam perjanjian TRIP'S dan dalam Konvensi Paris, Konvensi London maupun Konvensi Stokholm agar dapat terciptanya persaingan dan perdagangan bebas secara sehat di era Globalisasi saat ini.

Pada tahun 2016 yang lalu Pemerintah Indonesia mensahkan peraturan perundang-undangan terbaru yang mengatur mengenai Merek dan indikasi Geografis Nomor 20 Tahun 2016 yang menggantikan UU Merek terdahulu Undang-Undang Nomor 15 tahun 2001. Apakah setelah perubahan pengaturan mengenai Merek kepada Undang-undang baru tersebut dapat memberikan kepastian perlindungan hukum terhadap Merek terkenal yang tidak di daftarkan. Mengingat masih banyak nya pemilik Merek terkenal yang merasa sudah punya nama di dunia Internasional tidak mendaftarkan Mereknya di Indonesia.

Persoalan mengenai pelanggaran terhadap Merek terkenal di Indonesia mempunyai keunikan tersendiri. Karena yang terjadi Indonesia adalah si pemilik Merek terkenal lah yang malah digugat oleh pihak local, misalnya kasus yang menimpa Piere Cardin dan Levi's. penggunaan Merek terkenal secara melawan hukum yang mrak di Indonesia tidak dapat dipisahkan dari mental pengusaha local yang hanya ingin dengan proses yang instant dengan menggunakan Merek terkenal yang sudah punya konsumen tetap untuk mengembangkan produk buatan mereka sendiri.

\section{RUMUSAN MASALAH}

Berdasarkan latar belakang diatas, dalam artikel ini akan membahas mengenai bagaimana perlindungan merek terkenal yang tidak terdaftar berdasarkan UndangUndang Nomor 20 Tahun 2016 tentang Merek dan Indikasi Geografis?

\section{METODE PENELITIAN}

Penelitian hukum diperlukan untuk menampilkan hukum secara integral sesuai dengan kebutuhan kajian ilmu hukum itu sendiri. ${ }^{1}$ Metode penelitian yang dipakai dalam peneltian ini adalah menggunakan metode penelitian yuridis normative yaitu penelitian hukum yang dilakukan dengan cara meneliti bahan pustaka atau data skunder sebagai bahan dasar untuk diteliti dengan cara

1 Yati Nurhayati, (2013), "Perdebatan Antara Metode Normatif Dengan Metode Empirik Dalam Penelitian Ilmu Hukum Ditinjau Dari Karakter, Fungsi, dan Tujuan Ilmu Hukum" Jurnal Al Adl, Vol 5, No 10, hlm.15 
mengadakan penelusuran terhadap peraturan-peraturan dan literature-literatur yang berkaitan dengan permasalahan yang diteliti. $^{2}$ Dalam penelitian hukum normative ini maka teknik pengumpulan bahan hukum nya adalah menggunakan teknik pengumpulan bahan hukum primer, skunder dan tersier yang kemudian di kumpulkan lalu dianalisa dalam bentuk uraian di dalam hasil pembahasan.

\section{PEMBAHASAN}

Upaya Perlindungan Hukum Terhadap Pelanggaran Merek Terkenal Yang Tidak Terdaftar di Indonesia

Pada saat manusia mulai mengenal perdagangan merek menjadi suatu hal yang sangat penting, karena untuk membedakan dirinya dan produk yang dimiliki oleh para pesaingnya. Dalam hal ini merek menjadi peran penting dalam pencitraan dan strategi pemasaran perusahaan di mata konsumen. Citra dan reputasi perusahaan untuk menciptakan kepercayaan merupakan dasar untuk mendapatkan pembeli yang setia dan meningkatkan nama baik perusahaan.

Nilai komersial suatu merek menjadi semakin tinggi apalagi jika menyangkut Merek terkenal di

2 Soerjono Soekanto \& Sri Mamudji, (2001), Penelitian Hukum Normatif (suatu Tinjauan Singkat), Rajawali Pers, Jakarta, hlm.13-14
Mancanegara. Perlindungan utama yang diperoleh dari sebuah merek adalah melalui pendaftaran. Namun tingkat kesadaran orang akan pentingnya suatu Merek untuk didaftarkan masih sangat rendah. Adakalanya suatu merek asing yang terkenal tidak atau belum sempat untuk mendaftarkan Mereknya pada satu yurisdiksi suatu negara yang mana di negara tersebut ternyata merek tersebut sudah sangat terkenal. Oeh karena itulah diperlukan suatu aturan hukum yang berlaku secara nasional maupun internasional yang dapat melindungi merek asing terkenal dari pihak-pihak yang beritikad buruk yang ingin meniru, menjiplak atau mendompleng merek terkenal tersebut.

Sebelum diundangkannya Undang-undang Nomor 20 tahun 2016 Tentang Merek dan Indikasi geografis mengenai Hak Merek telah diatur dalam Undang-undang Nomor 15 Tahun 2001. Meskipun demikian kedua aturan perundang-undangan tersebut tidak ada memuat mengenai ketentuan khususnya aturan pidana terhadap merek terkenal yang tidak terdaftar. Padahal dalam konvensi Paris diamanatkan untuk memberikan perlindungan terhadap merek terkenal baik yang didaftarkan maupun yang tidak terdaftar. 
Salah satu prinsip terpenting dari Konvensi Paris adalah prinsip tentang persamaan perlakuan yang mutlak antara orang asing dan warga negara sendiri. Prinsip tersebut dirumuskan dalam pasal 2. Pasal tersebut mengandung prinsip "National Treatment" atau prinsip asimilasi (principle assimilation) yaitu seseorang warga negara yang merupakan warga dari suatu negara peserta Uni, akan memperoleh pengakuan dan hak-hak yang sama seperti seorang warga negara dimana mereknya didaftarkan. ${ }^{3}$

Ketentuan untuk melindungi merek terkenal di atas berlaku bagi seluruh negara anggota konvensi Paris dan penandatangan perjanjian TRIPs dan Indonesia salah satu negara yang juga turut serta meratifikasi kedua perjanjian tersebut yaitu melalui Kepres No.15 Tahun 1997 dan Kepres NO.7 tahun 1994.

Sebagaimana yang termuat dalam pasal 6 bis konvensi Paris terdapat beberapa prinsip sederhana, yaitu:

$$
\begin{aligned}
& \text { 1. negara peserta diminta } \\
& \text { menolak } \text { (baik } \\
& \text { berdasarkan perundang- } \\
& \text { undangan merek yang } \\
& \text { dimiliki atau permintaan } \\
& \text { pihak yang }
\end{aligned}
$$

\footnotetext{
Muhammad Djumahana dan R Djubaedillah, (2014), Hak Milik Intelektual sejarah, teori dan praktiknya di Indonesia, Bandung: PT Citra Aditya Bakti, hlm.233
}

berkepentingan)

permintaan pendaftaran atau pembatalan pendaftaran pendaftaran dan melarang penggunaan merek yang sama dengan atau merupakan tiruan, dan atau dapat menimbulkan kebingungan (dan seterusnya) dari suatu merek yang:

a. menurut

pertimbangan pihak yang berwenang di negara penerima pendaftaran

merupakan merek terkenal atau telah dikenal luas sebagai merek milik seseorang yang berhak memperoleh perlindungan sebagaimana diatur dalam konvensi

b. digunakan pada produk yang sama atau sejenis.

2. Jangka waktu permintaan pembatalan setidaknya setahun terhitung sejak tanggal 
pendaftaran (merek

yang menyerupai merek

terkenal tersebut)

3. Kalau pendaftaran dilakukan dengan itikad buruk tidak ada batas waktu untuk menentukan pembuktian.

Indonesia menganut system first to file yaitu dimana pihak pertama yang mengajukan permohonan pendaftaran hak merek mendapat prioritas untuk terlebih dahulu dalam pendaftaran Hak merek maka akan mendapatkan Hak eksklusif atas mereknya dan mendapat perlindungan hukum. Maka ketentuan ini berbeda dengan norma yang dianut pada UndangUndang No.28 Tahun 2014 tentang Hak Cipta yang menganut asas first to use. ${ }^{4}$

Secara hak ekslusif dapat didefinisikan sebagai hak "memberikan jaminan perlindungan kepada pemilik merek dan merupakan pemilik satusatunya yang berhak memakai dan mempergunakan serta melarang siapa saja untuk memiliki dan mempergunakannya". Dengan demikian hak ekslusif memat dua hal yaitu pertama, menggunakan merek

4 Yati Nurhayati, Ifrani, Abdul Halim Barkatullah, dan M. Yasir Said, (2019), "The Issue of Copyright Infringement in 4.0 Industrial Revolution: Indonesian Case", Jurnal Media Hukum, Vol. 26 No. 2, December, hlm.124 tersebut dan yang kedua memberikan ijin kepada pihak lain untuk dapat menggunakan merek tersebut. Hal ini merupakan upaya untuk melindungi masyarakat dari perbuatan sewenangwenang yang tidak sesuai dengan aturan hukum, untuk mewujudkan ketertiban dan ketentraman. $^{5}$

Apabila suatu merek telah dikategorikan sebagai merek terkenal, maka akan sangat diperlukan suatu perlindungan hukum agar merek tersebut tidak dibajak oleh orang lain ataupun ditiru. Merek sering disalahgunakan untuk menumpang ketenaran suatu produk dengan merek tertentu. Banyak pelaku usaha yang mendaftarkan merek sengaja memiripkan dengan merek dagang terkenal sebagai upaya untuk mengelabui konsumen. Hal tersebut dapat dikatakan sebagai pendaftaran merek dengan iktikad tidak baik (bad faith). ${ }^{6}$

Ada 2 macam cara perlindungan yaitu dengan cara preventif dan repressive. Dengan cara preventif adalah dengan dititikberatkan pada upaya untuk mencegah merek terkenal tersebut

${ }^{5}$ Setiono, (2004), Rule of Law (Supremasi Hukum), Surakarta; Magister Ilmu Hukum Program Pascasarjana Universitas Sebelas Maret, hlm. 3.

${ }^{6}$ Mukti Fajar, Yati Nurhayati, dan Ifrani, (2018), "Iktikad Tidak Baik dalam Pendaftaran dan Model Penegakan Hukum Merek di Indonesia", Jurnal Hukum Ius Quia Iustum, Vol. 25, No. 2 Mei, hlm. 220 
dipakai dan ditiru oleh orang lain secara salah. Ada beberapa upaya preventif yang dimaksud adalah melalui penolakan oleh kantor merek jika ada pendaftaran yang dilakukan oleh orang lain dengan meniru merek terkenal yang sudah ada. Perlindungan merek melalui pendaftaran pada hakikatnya ditujukan untuk kepastian hukum atas merek terdaftar, baik untuk digunakan, diperpanjang, dialihkan maupun dihapuskan sebagai alat bukti bila terjadi pelanggaran atas merek terdaftar.

Cara perlindungan yang kedua adalah perlindungan hukum refresif. terhadap Merek apabila terjadi sengketa. Perlindungan refresif dapat berupa upaya penyelesaian sengketa sebagaimana yang diatur dalam ketentuan UU Merek maka dapat ditempuh secara Litigasi (pengadilan) maupun melalui jalur non litigasi yang mana diatur dalam dalam pasal 93 mengenai arbitrase atau alternative penyelesaian sengketa.

Dalam penyelesaian refresif peran dari para penegak hukum seperti kepolisian, dan kejaksaan menjadi sangat diperlukan. Pemilik merek terdaftar mendapat perlindungan hukum atas pelanggaran hak Merek dapat melalui gugatan ganti rugi maupun tuntutan hukum pidana melalui aparat penegak hukum. Selain itu pemilik merek terkenal juga dapat melakukan pembatalan merek.
Berkaitan dengan merek terkenal sebenarnya dalam banyak kasus pengadilan telah memperluas perlindungan hukum merek tersebut, yaitu mencakup perlindungan hukum bagi merek terkenal baik untuk barang yang sejenis maupun bukan.

Keseriusan pemerintah dalam upaya melidungi Hak Kekayaan intelektual Khususnya Hak Merek yang ada di Indonesia sudah dibuktikan dengan menyempurnakan peraturan hukum yang berlaku salah satu bentuk nyata nya adalah dengan lahirnya UU Nomor 20 Tahun 2016 Tentang Merek dan Indikasi Geografis yang merupakan perubahan atas UU Nomor 15 tahun 2001 Tentang Merek yang mana di dalam ketentuan UU yang baru mengenai Merek tersebut sudah lebih baik dibandingkan UU Merek yang lama khususnya dalam upaya perlindungan Merek terkenal yang tidak terdaftar di Indonesia.

Proses Pendaftaran Merek Terkenal menurut UU Nomor 20 Tahun 2016 tentang Merek dan Indikasi Geografis.

Indonesia menganut system pendaftaran konstitutif dimana dalam system ini mengharuskan adanya pendaftaran Merek agar suatu Merek bisa mendapatkan perlindungan system ini dikenal dengan system first to file. Yang 
mana dalam system ini menegaskan bahwa orang yang pertama kali mendaftarkan Merek maka dialah orang yang berhak atas Merek tersebut. Walaupun Indonesia menganut system konstitutif, perlindungan merek terkenal yang belum terdaftar di Indonesia tetap akan mendapat perlindungan karena Indonesia sudah meratifikasi Konvensi Paris dan perjanjian TRIPS. $^{7}$

Prinsip First to file yang dianut oleh system perlindungan merek di Indonesia membuat siapapun (baik perseorangan maupun badan hukum) yang pertama kali mendaftarkan suatu merek untuk kelas dan jenis barang/jasa tertentu dianggap sebagai pemilik hak atas merek yang bersangkutan untuk kelas dan jenis barang/jasa tersebut.

Pengaturan mengenai proses pendaftaran yang diatur dalam UU Nomor 20 tahun 2016 tentang Merek dan indikasi Geografis telah dipersingkat dibandingkan dengan proses pendaftaran yang diatur oleh UU Nomor 15 Tahun 2001. Dalam UU Merek yang baru proses dipersingkat menjadi permohonan kemudian pemeriksaan formal, kemudian pengumuman yang akan diberikan selama 2 bulan untuk menunggu apabila ada

\footnotetext{
${ }^{7}$ Yahya Harahap, (1996), Tinjauan Merek Secara Umum, Bandung: PT Citra Aditya Bakti, hlm.14
}

keberatan dan kemudian pemeriksaan substantive yang dilakukan selama 150 hari lalu kemudian sertifikasi. Sedangkan di dalam UU merek yang lama setelah diajukan permohonan, dilakukan pemeriksaan formal lalu kemudian pemeriksaan substantive yang memakan waktu lebih lama sekitar 9 bulan dan lalu pengumuman yang berlngsung untuk waktu 3 bulan lalu sertifikasi.

UU Merek mengatur 2 cara pendaftaran merek, yaitu pendaftaran dengan hak prioritas dan pendaftaran dengan cara biasa. Permohonan hak dengan prioritas diatur dalam pasal 9 dan 10 UU Merek. Sedangkan pengertiannya diatur dalam pasal 1 huruf yang dimaksud dengan hak otoritas adalah hak pemohon untuk mengajukan permohonan yang berasal dari negara yang tergabung dalam Paris Convention For The protection of Industrial Property atau Agreement Establishing The World Trade Organization dengan jangka waktu persetujuannya adalah paling lama 6 bulan terhitung sejak tanggal penerimaan permohonan pendaftaran merek yang pertama kali diterima di negara lain yang merupakan anggota Konvensi Paris atau anggota persetujuan Pembentukan Organisasi Perdagangan Dunia”.

Merek menganut prinsip territorial, yang artinya perlindungan 
merek hanya berlaku di negara mana merek tersebut dimohonkan dan diberi hak atas merek tersebut. Untuk mendapatkan perlindungan merek di Indonesia maka sang pemilik merek harus mengajukan permohonan merek di Indonesia, namun dengan didaftarkannya suatu merek di Indonesia tidak serta merta merek tersebut mendapat perlindungan hukum atas mereknya di negara lain.

Untuk mendapatkan perlindungan di luar negeri, maka pemohon harus mendaftarkan sendirisendiri di masing-masing negara yang dikehendaki dengan menunjuk konsultan HKI terdaftar yang wilayah kerjanya meliputi negara tersebut untuk menjadi kuasa permohonan pendaftaran merek. Dalam kurun waktu 6 bulan sejak tanggal penerimaan pertama kali di Indonesia pemohon bisa mengajukan permohonan pendaftaran untuk merek yang sama untuk barang/jasa sejenis di negara lain yang sama-sama menjadi anggota Konvensi Paris dan mendapatkan tanggal penerimaan yang sama dengan tanggal penerimaan di Indonesia dengan menggunakan Hak Prioritas seperti yang sudah dijelaskan di atas. Tujuan utama pemberian hak prioritas pada saat akan memperoleh pendaftaran merek di Indonesia adalah untuk melindungi pemilik merek dari pelanggaran merek seperti peniruan, pembajakan. $^{8}$

Beberapa negara sudah menerapkan system pendaftaran merek terpusat, sebagai contoh di Benelux (Belanda, Belgia, Luxemburg) dimana merek tersebut akan terdaftar sekaligus mendapat perlindungan hukum di tiga negara tersebut. Begitupun di Uni Eropa melalui system OHIM juga menerapkan system serupa untuk sekitar 22 negara di Eropa. Namun system ini mempunyai kelemahan, yaitu apabila pada masa pemeriksaan merek yang didaftar tertolak di satu negara anggota maka akan berpengaruh pada seluruh permohonan. Sehingga banyak pemohon yang lebih memilih untuk mendaftarkan sendirisendiri di setiap negara. ${ }^{9}$

Dalam pasal 52 UU Nomor 20 tahun 2016 tentang Merek dan Indikasi Geografis menambah ketentuan mengenai "permohonan pendaftarn merek internasional" yaitu mengenai permohonan yang berasal dari Indonesia ditujukan ke Biro internasional dan permohonan yang ditujukan ke Indonesia sebagai salah satu negara tujuan dari Biro Internasional. Selanjutnya ketentuan lebih lanjut

8 Iswi Hariyani, (2010), Prosedur Mengurus HAKI yang Benar, Yogyakarta: Pustaka Yustisia, hlm.54

${ }^{9}$ Sudarmanto, (2012), KI dan HKI serta Implementasinya Bagi Indonesia, Jakarta: PT Elex Media Komputindo, hlm.22 
mengenai pendaftaran merek internasional berdasarkan Protocol Relating To the Madrid Agreement Concerning the International Registration of Marks yang kemudian diatur lebih lanjut dalam Peraturan Pemerintah.

Selain konvensi Paris, terdapat juga konvensi lain seperti perjanjian Madrid 1891. Perjanjian Madrid dibentuk pada April 1891. Tujuan pembentukannya adalah mempermudah cara pendaftaran merek di berbagai negara secara sekaligus, yaitu di negara-negara peserta Konvensi Paris menghindarkan pemeberitahuan asal barang secara palsu (Madrid Agreement Concerning The Repression of False Indication of False Origin), pendaftaran internasional terhadap merek nasional di biro internasional di Bern dengan pengertian bahwa merek-merek tersebut harus terlebih dahulu menjadi merek nasional di negara asalnya. ${ }^{10}$

Konsep dasar Madrid Protocol adalah satu aplikasi merek untuk mendapatkan perlindungan hukum di banyak negara. Dimana apabila calon pendaftar merek ingin mendaftarkan merek miliknya di banyak negara maka cukup hanya mengajukan permohonan ke Direktorat Merek Drektorat Jendral Hak Kekayaan Intelektual Departemen Hukum

10 Sudrajat, dkk., (2010), Hak Kekayaan Intelektual, Bandung: Oase Media, hlm.66 dan HAM tertentu saja tidak perlu datang ke masing-masing negara yang dituju. Dengan demikian, apabila Indonesia tidak meratifikasi Madrid Protocol maka pemilik merek dari dalam negeri mau tidak mau harus mendaftarkan mereknya disetiap negara. Dan saat ini UU Merek Nomor 20 Tahun 2016 telah mengadopsi perjanjian Madrid Protocol. ${ }^{11}$ Indonesia sudah resmi menjadi anggota Madrid Protocol yang ke 100 di Depan Sidang Umum World Intellectual Property Organization (WIPO) ke 57 di Jenewa senin 2 Oktober 2017. Untuk menindaklanjuti hal tersebut pemerintah Indonesia melalui Presiden Jokowi menandatangani Peraturan Presiden (perpres Nomor 92 Tahun 2017 tentang Aksesi protocol Madrid.

\section{PENUTUP}

Keseriusan pemerintah dalam upaya melidungi Hak Kekayaan intelektual Khususnya Hak Merek yang ada di Indonesia sudah dibuktikan dengan menyempurnakan peraturan hukum yang berlaku salah satu bentuk nyata nya adalah dengan lahirnya UU Nomor 20 Tahun 2016 Tentang Merek dan Indikasi Geografis yang merupakan perubahan atas UU Nomor 15 tahun 2001 Tentang Merek

11 Rizaldi, Julius, 2009, Perlindungan kemasan Produk Merek Terkenal Terhadap Persaingan Curang, Bandung: PT Alumni, hlm.15 
yang mana di dalam ketentuan UU yang baru mengenai Merek tersebut sudah lebih baik dibandingkan UU Merek yang lama khususnya dalam upaya perlindungan Merek terkenal yang tidak terdaftar di Indonesia.

Untuk mendapatkan perlindungan di luar negeri, maka pemohon harus mendaftarkan sendiri-sendiri di masingmasing negara yang dikehendaki dengan menunjuk konsultan HKI terdaftar yang wilayah kerjanya meliputi negara tersebut untuk menjadi kuasa permohonan pendaftaran merek. Dalam kurun waktu 6 bulan sejak tanggal penerimaan pertama kali di Indonesia pemohon bisa mengajukan permohonan pendaftaran untuk merek yang sama untuk barang/jasa sejenis di negara lain yang sama-sama menjadi anggota Konvensi Paris dan mendapatkan tanggal penerimaan yang sama dengan tanggal penerimaan di Indonesia dengan menggunakan Hak Prioritas. Dalam pasal 52 UU Nomor 20 tahun 2016 tentang Merek dan Indikasi Geografis menambah ketentuan mengenai "permohonan pendaftarn merek internasional" yaitu mengenai permohonan yang berasal dari Indonesia ditujukan ke Biro internasional dan permohonan yang ditujukan ke Indonesia sebagai salah satu negara tujuan dari Biro Internasional. Selanjutnya ketentuan lebih lanjut mengenai pendaftaran merek internasional berdasarkan Protocol Relating To the Madrid Agreement Concerning the International Registration of Marks yang kemudian diatur lebih lanjut dalam Peraturan Pemerintah. Saat ini Indonesia sudah resmi menjadi anggota Madrid Protocol yang ke. 100 sehingga memudahkan dalam proses pendaftaran yang akan berlaku di 99 negara anggota Madrid Protocol

\section{DAFTAR PUSTAKA}

Djubaedillah, R dan Muhamad Djumhana, (2014), Hak Milik Intelektual Sejarah, Teori dan Praktiknya di Indonesia, Bandung: PT Citra Aditya Bakti

Harahap, Yahya, (1996), Tinjauan Merek secara Umum, Bandung: PT Citra Aditya Bakti,

Hariyani, Iswi, (2010), Prosedur Mengurus HAKI yang Benar, Yogyakarta: Pustaka Yustisia

Mukti Fajar, Yati Nurhayati, dan Ifrani, (2018). "Iktikad Tidak Baik dalam Pendaftaran dan Model Penegakan Hukum Merek di Indonesia", Jurnal Hukum Ius Quia Iustum, Vol. 25, No. 2 Mei

Rizaldi, Julius, (2009), Perlindungan kemasan Produk Merek Terkenal Terhadap Persaingan Curang, Bandung: PT Alumni 
Sudrajat dkk, (2010), Hak Kekayaan Intelektual, Bandung: Oase Media

Soerjono Soekanto \& Sri Mamudji, 2001, Penelitian Hukum Normatif (Suatu Tinjauan Singkat), Jakarta: Rajawali Pers

Setiono, (2004), Rule of Law (Supremasi Hukum), Surakarta; Magister Ilmu Hukum Program Pascasarjana Universitas Sebelas Maret.

Sudarmanto, (2012), KI dan HKI serta Implementasinya Bagi Indonesia, Jakarta: PT Elex Media Komputindo

Undang-Undang Nomor 20 Tahun 2016 Tentang Merek dan Indikasi Geografis

Yati Nurhayati, (2013). "Perdebatan Antara Metode Normatif Dengan Metode Empirik Dalam Penelitian Ilmu Hukum Ditinjau Dari Karakter, Fungsi, dan Tujuan Ilmu Hukum" Jurnal Al Adl, Vol 5, No 10.

Yati Nurhayati, Ifrani, Abdul Halim Barkatullah, dan M. Yasir Said, (2019), "The Issue of Copyright Infringement in 4.0 Industrial Revolution: Indonesian Case", Jurnal Media Hukum, Vol. 26 No. 2, December. 